\title{
Intelligence Cooperation in the European Union: An Impossible Dream?
}

\author{
Şeniz Bilgi \\ Middle East Technical University
}

\begin{abstract}
There has been a shift in the intelligence and security strategies of the states since 9/11. The attacks created a new security environment in which intelligence has become increasingly significant. Not only have the responsibilities and tasks of intelligence agencies become more important, but the necessity for intelligence and security service cooperation among nations has also increased. Accordingly, intelligence agencies had to update their strategies to put more emphasis on collaboration. This article analyzes the current EU intelligence network and tries to answer whether full intelligence cooperation in the EU could develop into a discrete organization in the aftermath of 2004 Madrid, 2005 London and the 7 January 2015 Charlie Hebdo attacks, or whether it is an impossible dream to have concerted action whereby states acknowledge their mutual alliances, interests, and strategies.
\end{abstract}

Keywords: Intelligence, European Union, intelligence organizations, intelligence cooperation, terrorism

\section{Introduction}

The term intelligence refers to the process in which any kind of information is collected, analyzed, evaluated, and presented to decision makers to prevent tactical or strategic surprises. Intelligence has always been a crucial part of the security strategies of the states especially during the Cold War, but a shift in such strategies has been observed since the 2001 9/11 attacks. These attacks created a new security environment (including, but not limited to international terrorism, organized crime, pandemics, the proliferation of weapons of mass destruction and internet crime), in which intelligence has become increasingly significant. Therefore, not only have the responsibilities and tasks of intelligence agencies become more important, but the necessity for intelligence and security service cooperation among nations is also increasing. As a result, intelligence agencies have had to change their strategies of intelligence collection, processing, and analysis to place more importance on collaboration.

The 2004 Madrid and 2005 London attacks solidified that global (or transnational) terrorism and crime affect all states. These events, as well as the drastic changes to the international politics arena in the aftermath of $9 / 11$, have necessitated concerted action whereby states acknowledge their mutual alliances, interests, and strategies. Hence, cooperation efforts in the field of intelligence, which emphasizes shared beliefs and interests, have intensified. Such efforts have been either bilateral, as between the US and the UK, or multilateral, as 
among NATO's member states (such as the UKUSA agreement among the US, the UK, Australia, Canada, and New Zealand, ${ }^{1}$ as well as the Kilowatt Group, ${ }^{2}$ which includes EU member states, Canada, Norway, Switzerland, Sweden, the US, Israel, and South Africa). ${ }^{3}$ Such agreements also exist within the EU itself, and it is these cooperation agreements and efforts that I focus on in this paper.

I first deal with the current state of intelligence cooperation and the mechanisms of such cooperation within the EU. Second, I analyze the effectiveness and efficiency of existing EU intelligence cooperation with respect to the steps of the intelligence process. Third, I elaborate on the overall evaluation of the current intelligence-sharing framework to determine whether the current system meets the needs of the EU as an effective political actor in the new security environment. Fourth, I focus on the recent Al Qaeda attack on the Charlie Hebdo newspaper in Paris and what it represents in terms of long-needed intelligence cooperation within the EU. Finally, I try to answer whether full intelligence cooperation in the EU could develop into a discrete organization or whether it is an impossible dream.

\section{Intelligence Cooperation within the $\mathbf{E U}$}

As noted earlier, intelligence cooperation is one of the most significant items on states' agendas, and the EU is no different. Since the Cold War years, intelligence cooperation has occurred between groups with different foci but the same aim, which is to protect the European continent. The next section presents an analysis and explanation of such groups and efforts.

\subsection{The Club of Berne}

Founded in 1971, the Club of Berne is a forum of EU member states, Switzerland and Norway, developed to enable the exchange of classified information, particularly on terrorism and subversion. ${ }^{4}$ The Club has a rotating chair, and holds regular meetings, technical conferences, and investigation operations, and has its own communications system. ${ }^{5}$ It has also established working groups on terrorism and organized crime, which led to the creation of the Counter Terrorism Group (CTG), elaborated on below. The Club of Berne does not base its activities on the formal EU charter and therefore operates outside EU institutions. ${ }^{6}$ In addition, the group does not expect that all members will share relevant intelligence with the other members $;{ }^{7}$ in other words, intelligence sharing or exchange of intelligence, experience, and/ or data within the Club is on a voluntary basis.

1 Originating in 1941, the UKUSA is a multilateral agreement for cooperation in signals intelligence between the mentioned countries. It facilitates the exchange of products from the collection of traffic, acquisitions of communication and equipment, traffic analysis, cryptanalysis, decryption, and translation and acquisition of information regarding communications organizations, procedures, practices, and equipment.

2 Formed in 1977 especially as a response to 1972 Munich Olympics events, the Kilowatt Group cooperates around intelligence services on counterterrorism.

3 Stéphane Lefebvre, "The Difficulties and Dilemmas of International Intelligence Cooperation," International Journal of Intelligence and Counterintelligence 16, no. 4 (2003): 527-42.

4 Fred Schreier, WMD Proliferation: Reforming the Security Sector to Meet the Threat (Virginia: Potomac Books, 2009).

5 Lefebvre, "The Difficulties and Dilemmas."

6 I. James Walsh, "Intelligence Sharing in the European Union: Institutions Are Not Enough," JCMS 44, no. 3 (2006): 625-43.

7 Walsh, "Intelligence Sharing." 


\subsection{Europol}

Europol is the EU's law enforcement agency; it was created in 1995 by a convention signed by all member states and began operations in 1999. Its main responsibility is to make Europe a safer place by assisting member states in their fight against international terrorism and crime. ${ }^{8}$ Europol focuses on transnational trafficking in drugs, human beings, and vehicles, as well as illegal immigration, terrorism, forgery, money-laundering, and cybercrime. ${ }^{9}$ It also acts as the major centre of expertise in the key fields of law enforcement activity and as a European centre for strategic intelligence on organized crime. ${ }^{10}$ Although Europol has no direct powers of arrest, ${ }^{11}$ it supports other law enforcement agencies by gathering, analyzing, and disseminating information, and by coordinating investigations, especially in the area of organized crime. $^{12}$

Each member state is represented at Europol headquarters in The Hague by a European liaison officer, who is required to share relevant intelligence on behalf of his or her state. However, the main mechanism of intelligence sharing in the institution is the Europol computer system, known as TECS. The system consists of two different types of intelligence, the first of which is mainly concerned with perpetrators' basic identifying characteristics, and the second of which are the work files providing relevant information on specific offences. ${ }^{13}$ The TECS system consists of three modules: 1) the Europol information system about suspects who have committed or are involved in organized crime, 2) an analysis records system studying specific criminal phenomena and groups, and 3) an index system allowing Europol liaison officers and non-participating states to consult inventory data stored in the system. ${ }^{14}$

\subsection{European Union Military Staff (EUMS)}

The EUMS is the source of the EU's military expertise, and is comprised of military experts seconded from member states to the Council Secretariat. The organization provides an earlywarning capability by planning, assessing, and making recommendations regarding crisis management and general military strategy. ${ }^{15}$ The EUMS works under the guidance of the European Union Military Committee (EUMC) by implementing its decisions and supporting it in situation assessments and the military aspects of strategic planning.

The EUMS is also a center for intelligence sharing to support the EU's Common Security and Defence Policy (CSDP). This task is carried out by the group's Intelligence Directorate, whose mission is to provide intelligence input to early warning and situation assessments, contribute to EUMS planning through providing intelligence and intelligence planning expertise, and provide intelligence input to crisis response planning and assessments of operations and exercises. ${ }^{16}$ The Directorate uses intelligence shared by member states as

\footnotetext{
8 Europol official webpage, accessed August 20, 2010, http://www.europol.europa.eu/index.asp?page=introduction.

Walsh, "Intelligence Sharing."

Europol official webpage.

${ }^{11}$ Europol official webpage (Europol profile), accessed August 20, 2010, http://www.europol.europa.eu/index.asp?page=facts

12 Europol profile.

13 Walsh, "Intelligence Sharing."

14 Frederic Lemieux, "Information Technology and Criminal Intelligence: A Comparative Perspective," in Technocrime: Technology, Crime and Social Control, ed. Stephane Leman-Langlois (Willan Publishing: London, 2013), 139-68.

15 European Union Law, Military Staff of the European Union, accessed August 17, 2010, http://europa.eu/legislation summaries/foreign_and_security_policy/cfsp_and_esdp_implementation/r00006_en.htm.

16 "Providing Military Capabilities to the EU," European Union Military Staff, accessed August 20, 2010, http://www. consilium.europa.eu/uedocs/cmsUpload/EUMS-June-2010.pdf.
} 
well as intelligence gathered by other EU bodies to produce assessments for the Military Committee, the EU's High Representative for foreign policy, and other EU organizations. ${ }^{17}$

\subsection{The Counterterrorism Group (CTG)}

The CTG is an offshoot of the Club of Berne, created after $9 / 11$ to further intelligence sharing among the European intelligence structures. Mainly working in the area of terrorism intelligence, it cooperates with member states in an extra-legal and secret understanding and its main focus is conducting threat assessments about extremist Islamic terrorism. ${ }^{18}$

The CTG does not have its own sources, thus it works in cooperation with the other intelligence bodies within the EU. It channels its strategic and tactical intelligence analyses to the EU Intelligence Analysis Centre (INTCEN), which provides the Union with a streamlined internal and external analysis capability. ${ }^{19}$

\subsection{The European Union Satellite Centre}

Located in Torrejon, Madrid, the Satellite Centre is the EU's body concerned with geospatial intelligence, providing "geospatial products resulting from the analysis of satellite imagery and collateral data in order to support the operations and missions of the European Union and its Member States. ${ }^{\prime 20}$ Examples of such operations and missions include, but are not limited to, PROXIMA and CONCORDIA (both in the former Yugoslav Republic of Macedonia), EUFOR-ALTHEA (in Bosnia Herzegovina), and EUJUST LEX (in Iraq). ${ }^{21}$

\subsection{The EU Joint Situation Centre (SitCen) and INTCEN}

Originating from the European Security and Defence Policy of 1999, SitCen, INTCEN's predecessor, was responsible for providing the Council with high-quality information on matters of public security in the form of early warnings, assessments, and services in cases of emergency. It also constituted a contact between the High Representative and the intelligence community of EU countries.

SitCen's intelligence sources derived mainly from the seven countries in the EU at the time of its formation (France, Germany, Italy, the Netherlands, Spain, Sweden, and the UK), who thus also shaped the perception of a terrorist threat to the EU and the development of countermeasures to it. ${ }^{22}$ SitCen was responsible for analyzing not only external threats to the EU but also internal threats, which included internal security, intelligence investigations, border surveillance, and crisis management. ${ }^{23}$

Renamed and restructured as INTCEN in 2012, the organization comprises intelligence institutions from all countries currently in the EU. Tasked with providing intelligence analyses, early warnings, and situational awareness to EU states and institutions in the fields of security, defence, and counter terrorism, INTCEN also influences member states' intelligence decision-making processes.

17 Walsh, "Intelligence Sharing."

18 Jelle van Buuren, Secret Truth: The EU Joint Situation Centre (Amsterdam: Eurowatch, 2009).

19 van Buuren, Secret Truth.

20 The European Union Satellite Centre official webpage, accessed August 25, 2010, http://www.eusc.europa.eu/index. php?option $=$ com_content\&task $=$ view\&id=7\&Itemid $=15$.

21 For more detailed information on the Centre's activities, visit its webpage, http://www.eusc.europa.eu/.

22 van Buuren, Secret Truth.

23 van Buuren, Secret Truth. 
The institution's main functions include: ${ }^{24}$

- providing information not available overtly or not provided elsewhere;

- providing assessments, briefings, and a range of products based on intelligence and open sources;

- acting as a single entry point in the EU for classified information coming from member states' civilian intelligence and security services; and

- supporting and assisting the presidents of the European Council and Commission in the exercise of their respective functions in the area of external relations.

INTCEN currently operates within two divisions: the Analysis Division, which is tasked with providing strategic analysis based on input from member states' security and intelligence services, and the General and External Relations Division, which works on legal, administrative, and information technology issues, and undertakes open source analysis. ${ }^{25}$ INTCEN is also responsible for preparing special reports that are usually thematic or based on a topic of current interest and intelligence summaries on risks for EU personnel in any given country. ${ }^{26}$

\section{Effectiveness and Efficiency of Current Intelligence Cooperation within the EU}

This section analyzes the strengths and the weaknesses of the current intelligence cooperation within the EU to determine whether the system is effective. I take the steps in the intelligence cycle (process) (i.e. collection, processing, analysis and evaluation, dissemination, and tasking and control) as the basis for analysis, as done by Müller-Wille in his 2002 and 2008 studies. ${ }^{27}$ I choose this approach to provide an overview of the framework of the EU intelligence process rather than focusing on each organization.

Collection: Apart from the EU Satellite Centre, no joint resource exists for intelligence collection in the EU. As Cross states, the EU has "no formal mandate in intelligence gathering." ${ }^{28}$ Therefore, each member state collects intelligence from its own sphere of interest (i.e. southern states deal with the south, northern states deal with the north). ${ }^{29}$ When it comes to collecting open source intelligence, however, the EU is at an advantage as it benefits from its diplomatic missions worldwide. Moreover, it can also collect this type of intelligence through INTCEN's General and External Relations Division.

Processing: The Union is at a disadvantage at this stage of the intelligence cycle because it does not have its own processing capabilities. It uses the facilities of the Torrejon Satellite Centre, which does not, however, own or operate its own satellites but purchases commercial imagery and analyzes it for the EU and/or for individual member states. ${ }^{30}$

Analysis and Evaluation: According to Müller-Wille, the EU's capacity for analyzing crisis prevention and management is mainly in the civil sphere, which is not a problem in

\footnotetext{
24 INTCEN Fact Sheet, quoted in Chris Jones, “Analysis: Secrecy Reigns at the EU's Intelligence Centre,” Statewatch 22, no. 4 (2013), accessed May 24, 2014, http://www.statewatch.org/analyses/no-223-eu-intcen.pdf.

25 Jones, "Analysis."

26 INTCEN Fact Sheet quoted in Jones, "Analysis."

${ }^{27}$ For more detailed information, see Björn Müller-Wille, "EU Intelligence Co-operation. A Critical Analysis," Contemporary Security Policy 23, no. 2 (2002): 61-86 and Björn Müller-Wille, "The Effect of International Terrorism on EU Intelligence Cooperation," JCMS 46, no. 1 (2008): 49-73.

28 Mai'a K. Davis Cross, "EU Intelligence Sharing and The Joint Situation Centre: A Glass Half-Full” (paper prepared for delivery at the twelfth biennial conference of the European Studies Association, March 3-5, 2011, Boston, Massachusetts), accessed May 24, 2014, http://www.euce.org/eusa/2011/papers/3a_cross.pdf.

29 Müller-Wille, "EU Intelligence Co-operation."

30 Müller-Wille, "EU Intelligence Co-operation."
} 
itself because the EU is considered a primarily civil organization, ${ }^{31}$ but it means that the EU's civil capabilities cannot be integrated into the Common Foreign and Security Policy, thus resulting in the EU lacking a military intelligence and an analysis capacity. ${ }^{32}$ This issue, however, can be overcome, to some extent, with the capacities of the EUMS and INTCEN. ${ }^{33}$

Dissemination: Because the Union does not have its own collection sources, it depends on the contribution of national intelligence organizations for dissemination. Consequently, the EU cannot exercise any power on what intelligence can be shared and to what extent it will be shared. ${ }^{34}$ Because secrecy is the key to dissemination, this situation gives rise to an internal mistrust problem: How can secrecy be maintained when there is no open flow of internal information within the national agencies of the member states? ${ }^{35}$

Tasking and Control: The EU is again at a disadvantage in the tasking and control aspects of intelligence because it can request, but not demand or task, collection of specific intelligence or information. ${ }^{36}$ The EU can only control and task within its own limited analysis capacity. Nonetheless, just as in the analysis and evaluation step of the intelligence cycle, this disadvantage can be overcome through INTCEN through its own strategic analysis capacities; however, as that organization also has limited capabilities, tasking and control may not be able to be fully achieved in the EU due to the order of priority for the EU's preventive actions. For example, issues relating to the Middle East may dominate the EU's agenda of the EU, whereas issues related to the Balkans may not receive much attention.

After analyzing the steps of the intelligence process with respect to EU intelligence cooperation, one can argue that although institutions to share intelligence do exist, current mechanisms and beliefs do not let member states fully do so, thus limiting the EU's power against new threats to security and its influence as a global political actor in the new security environment. Specific examples of this situation can be seen within Europol and INTCEN. According to Europol, the organization does not have the ability to provide intelligence for European police operations conducted outside EU territory, such as those for organized crime or human trafficking. ${ }^{37}$ Europol also does not function effectively as a centralized intelligence agency offering support to national agencies. ${ }^{38}$ As for INTCEN, because, as noted above, it does not have a monopoly on intelligence, ${ }^{39}$ member states are the real decision makers in terms of what intelligence to share. Consequently, analyses provided by INTCEN may be subjective, perhaps reflecting the views of the intelligence contributors but not of the EU as a whole.

The above discussion reveals that intelligence cooperation within the EU has many weaknesses, outweighing the strengths, such as access to open source analyses via EU missions worldwide. Consequently, this situation necessitates an evaluation of the EU's current intelligence cooperation efforts and of the issues involved, such as obstacles to intelligence cooperation. The next section of the paper provides a general evaluation of these concerns.

\footnotetext{
31 Müller-Wille, "EU Intelligence Co-operation."

32 Müller-Wille, "EU Intelligence Co-operation."

33 Ilkka Salmi, quoted in Kristof Clerix, "Ilkka Salmi, the EU's Spymaster," Mondiaal Nieuws, accessed May 24, 2014, http:// www.mo.be/node/3789.

34 Müller-Wille, "EU Intelligence Co-operation."

35 Müller-Wille, "EU Intelligence Co-operation."

36 Müller-Wille, "EU Intelligence Co-operation."

37 Müller-Wille, "International Terrorism."

38 Müller-Wille, "International Terrorism."

39 Müller-Wille, "International Terrorism."
} 


\section{Overall Evaluation of Intelligence Cooperation Efforts in the EU}

Though desirable for all member states and the Union as a whole, intelligence cooperation within the EU is not fully occurring. A report by the UK's House of Lords' EU Committee on the EU's response to the Madrid bombings stated that the EU is "making an important contribution [to intelligence cooperation by] supporting Member States - who have the primary responsibility [for intelligence] - but its structures are complex and confusing and need to be streamlined." 40 The problematic status of the current framework can be linked to numerous factors, analyzed below.

One such factor is security, which goes hand in hand with the issue of trust. For all national intelligence agencies, protecting sources is critical to preventing security failures. For the EU, then, because intelligence sharing is on a voluntary basis ${ }^{41}$ and states are the decision makers in intelligence cooperation, member states can refrain from sharing sources or intelligence on the grounds that doing so will affect the security of their sources and may lead to security failures. Sharing sources can also be considered a breach of national security and a threat to sovereignty: member states are "unwilling to give up sovereignty in such a secretive and sensitive area." ${ }^{42}$ However, when states trust another state, this fear lessens, allowing intelligence to be shared more easily, such as in cases of global terrorism. Still, trust remains an issue, because although member states desire to cooperate, they do not want to risk spoiling "their privileged relationships with [non-EU] significant partners as a result of increased European exchanges." ${ }^{\prime 43}$ For example, the UK is unwilling to extend its existing intelligence cooperation with the US (i.e. cooperation in national security intelligence especially with respect to counterterrorism) to greater Europe in other areas of intelligence cooperation (e.g. law enforcement intelligence or criminal intelligence) because it does not want to threaten its relationship with the former ${ }^{44}$ (yet the Kilowatt Group functions as a counterterrorism intelligence cooperation organization among these parties). Cooperation with other intelligence agencies does not mean destroying or spoiling relations with current collaborators. On the contrary, such cooperation would benefit all states, allowing access to more valid and reliable sources of intelligence, which would limit intelligence failures.

Another obstacle relevant to the issue of trust, according to Politi, is that each EU intelligence agency has faith and confidence only in what it produces. In other words, states have no confidence in the intelligence produced by others, despite some intelligence interdependence inherent within the current system. ${ }^{45}$ Therefore, although non-confidence may appear to be an issue, member states must depend on each other in areas where they do not have full dominance because "broader political considerations tend to dictate a certain leeway in the way exchanges are managed." 46

The other obstacle in European intelligence cooperation is that "an agency belonging to a smaller country runs the risk of being infiltrated, influenced, controlled and ultimately

\footnotetext{
40 "Call for Better EU Intelligence Sharing to Tackle Terrorism," Politics, March 8, 2005, accessed August 28, 2010, http:// www.politics.co.uk/news/call-better-eu-intelligence-sharing-tackle-terrorism-\$30161.htm.

41 Walsh, "Intelligence Sharing."

${ }^{42}$ Mai'a K. Davis Cross, "A European Transgovernmental Intelligence Network and the Role of IntCen," Perspectives on European Politics and Society 14, no. 3 (2013): 388-402.

43 Alessandro Politi, "Why is a European Intelligence Necessary?" in Towards a European Intelligence Policy, ed. Alessandro Politi (Institute for Security Studies, 1998).

44 Politi, "European Intelligence Necessary?"

45 Politi, "European Intelligence Necessary?"

46 Politi, "European Intelligence Necessary?"
} 
swallowed by bigger partners." ${ }^{47}$ Smaller countries within the EU do not want to be dominated by the UK, France, and Germany. However, no nation in the EU wants to be dominant in the field of intelligence because it would likely be the target of severe criticism in the event of intelligence failures. As Politi (1998) states, no one country would be willing to take the whole blame for such occurrences, especially when it would have to "accept being constantly dwarfed [with regards to intelligence collection] worldwide." 48

On the other hand, some feel that INTCEN, as a trans-governmental intelligence agency, could achieve intelligence cooperation within the EU. ${ }^{49}$ As Cross (2013) maintains, the resistance of member states to share intelligence is not really a roadblock to creating a "European intelligence space" because the current relationship building and networking among intelligence professionals already results in sharing best practices and know-how to cope with the challenges brought by globalization and the information revolution. ${ }^{50}$ Although Cross has a point in this respect, I believe that currently, not more than a space can be achieved; cooperation might take place around 'soft' issues, but hard-core security issues will still remain in the domain of national intelligence agencies. For example, more cooperation could likely be achieved in transnational crime, but national security issues would probably remain excluded from the cooperation agenda.

Looking at obstacles to cooperation and the current state of the EU intelligence community, in which the Council has some responsibilities for strategic decision making but does not play a significant operational or tactical role ${ }^{51}$ in addressing new security threats, one might conclude that a central European intelligence agency may never be realized. However, the Paris attacks have once again shown that such an agency is a necessity; it is not possible to prevent such events by solely relying on one member state's intelligence mechanisms. The next section briefly explains what the Paris attacks have shown us in terms of the dire need for intelligence cooperation.

\section{The January 7 Charlie Hebdo Attack: Another Indicator of Required Intelligence Cooperation}

In this section, I briefly analyze why the recent Charlie Hebdo newspaper attack and the event's aftermath function as another indicator of long-needed intelligence cooperation within the EU. As noted at the beginning of this article, one of the most important functions of intelligence is to prevent tactical or strategic surprises. Nonetheless, the Charlie Hebdo attack was a bombshell for European states, especially France, of course. Although the magazine's writers had received threats from radical Islamists several times, an attack of such scale was completely unexpected.

Quoting Italian Prime Minister Matteo Renzi, Özcan puts forth that the Union should have a joint security and intelligence mechanism, just as it does with the joint currency unit. ${ }^{52}$ The EU's Achilles heel is the lack of a common foreign policy and security strategy. To overcome this weakness the Union needs to create a common intelligence framework and

${ }^{47}$ Politi, "European Intelligence Necessary?"

${ }^{48}$ Politi, "European Intelligence Necessary?"

${ }^{49}$ Cross, "European Transgovernmental Intelligence."

so Cross, "European Transgovernmental Intelligence."

1 Müller-Wille, "The Effect of International Terrorism."

52 Nihat Ali Özcan, "Avrupa Birliği’’nin İstihbarat Örgütü Kurma Arayıșı" [The Quest of the European Union to Set Up an Intelligence Organization] Milliyet, accessed January 28, 2015, http://www.milliyet.com.tr/avrupa-birligi-nin-istihbarat/gundem/ ydetay/1997738/default.htm. 
intelligence sharing system; it has become quite obvious that transnational terrorist and crime organizations such as Al Qaeda have militants who are EU citizens and need to be monitored.

However, as Özcan also notes, establishing such a strategy and system is a difficult task given the compartmentalized intelligence mechanisms throughout the 28 member states and these agencies' difficult relations with decision makers. ${ }^{53}$ Moreover, such an agency would likely be considered a serious bureaucratic and political issue because of the lack of trust among states $;{ }^{54}$ countries may avoid sharing what they have so as not to destroy their own intelligence sharing systems, such as the case between the UK and the US. As a result, although a joint EU intelligence agency seems like a necessity, establishing one may be an impossible dream, an issue I explore in the next section.

\section{EU Intelligence Cooperation: An Impossible Dream?}

" $[\mathrm{H}]$ ow a [central] intelligence agency might fit in the overall European Union mechanism and what its shape and role might be" may be difficult to determine, ${ }^{55}$ and given the factors discussed in the above sections, one might conclude that full intelligence cooperation in the EU may even be impossible. This belief may be strengthened by the fact that, for the following reasons, national security and defence identities are still dominant in operational and tactical responsibilities for fighting terrorism and organized crime. ${ }^{56}$ First, national agencies have more opportunities than an overarching EU body would to oversee operational and tactical responsibilities and are more able to do so due to their locations, integration within the system of national authorities and decision makers, knowledge of and established contacts within the underworld, and their societal and cultural knowledge. ${ }^{57}$ Second, national electorates still hold their own governments responsible for fighting terrorism and other threats within their territories. ${ }^{58}$ Third, policy-makers are only accountable to their citizens and governments, not to citizens of the EU as a whole or to any supranational authority.

However, the benefits of a central intelligence agency in the EU can be listed as follows: ${ }^{59}$ 1) more-coordinated efforts in gathering intelligence from different sources, such as open sources, 2) shared budgetary demands of intelligence collection and analysis, and 3) shared policy maker accountability.

From the information presented, it seems apparent that increased intelligence cooperation is important for the EU. This does not necessarily mean that the EU should have its own intelligence agency, as advocated by Nomikos (2003, 2004), who states that "compared to the Central Intelligence Agency in the U.S. political structure, the European Union Intelligence Agency should be independent and not part of any other institution within the European Union. ${ }^{\circ 60}$ Rather, it means that there should be more efforts to cooperate so that something that is not currently produced at any current level can be achieved. ${ }^{61}$ Although member states apparently prefer to cooperate mainly in the area of operational information pertaining to

\footnotetext{
53 Özcan, "The Quest of the European Union."

54 Özcan, "The Quest of the European Union."

5 John Nomikos, "Does the European Union Need a Common Intelligence Policy?" accessed August 18, 2010, http://www. worldsecuritynetwork.com/showArticle3.cfm?article_id=8661.

56 Nomikos, "Need a Common Intelligence Policy?"

57 Müller-Wille, "International Terrorism."

58 Müller-Wille, "International Terrorism."

59 These advantages are a summary of the benefits listed by Politi in "European Intelligence Necessary?"

${ }^{60}$ See Nomikos, "European Union Intelligence Agency"; and Nomikos, "Need a Common Intelligence Policy?" for his ideas on a European intelligence agency.

${ }^{61}$ Müller-Wille, "EU Intelligence Co-operation."
} 
the CSDP, no single national intelligence agency can cope with the demands of the new security environment. ${ }^{62}$ Increased cooperation should be designed in a way that would not weaken existing special relationships but strengthen them; ${ }^{63}$ this cooperation would offer better opportunities for information exchange so that all parties, including allies outside the EU, would benefit.

Planning for and implementing these changes require time and enormous effort, and perhaps the most important issue to focus on is dissolving the mistrust that exists between parties. Secret and sensitive information on issues specific to each member state could be kept within each national intelligence agency, but information relating to the $\mathrm{EU}$ as a whole should be shared so that the EU can more effectively and efficiently respond to threats from the new security environment.

\section{Conclusion}

In this paper I aimed to address the issue of intelligence cooperation within the EU. Although cooperation has gained more importance globally, especially within the new security environment, this has not been the case among EU member states. Although EU states have set up cooperation arrangements such as the Club of Berne, Europol, the EUMS and CTG, the European Union Satellite Centre, and INTCEN, none of these organizations serves as a central intelligence agency for the EU, mainly because of member states' personalized interests. Member states, especially the UK, France, and Germany, are hesitant to share intelligence with other parties and do not trust each other's intelligence sources. This situation inevitably leads to inadequate sources for intelligence collection and analysis. Furthermore, the fact that the EU has no supranational authority to exercise tasking and control means that each national intelligence service is only engaged in activities in its own spheres of interest, thus information that may benefit the EU as a whole must be cobbled together from various sources, and activities that may counter terrorism and organized crime are perhaps not being implemented.

Greater intelligence cooperation would result in professional, financial, and political advantages, allowing the EU to pursue a more effective security and defence policy and be a more effective actor in the global political arena. Because of these benefits, the relevant actors in EU intelligence should seriously consider increasing cooperation. Such changes, however, mostly depend on changes at the national level. For now, a central European intelligence agency may be an impossible dream, but initiating more attempts at cooperation is well within reach.

\section{Bibliography}

van Buuren, Jelle. Secret Truth. The EU Joint Situation Centre. Amsterdam: Eurowatch, 2009.

Clerix, Kristof. “Ilkka Salmi, the EU's Spymaster.” Mondiaal Nieuws. Accessed May 24, 2014. http://www.mo.be/ node/3789.

Cross, Davis Mai'a K. “EU Intelligence Sharing and Joint Situation Centre: A Glass Half-Full.” Paper prepared for delivery at the Meeting of the European Studies Association, 2011. Accessed May 24, 2014. http://www.euce. org/eusa/2011/papers/3a_cross.pdf.

— . "A European Transgovernmental Intelligence Network and the Role of IntCen." Perspectives on European

\footnotetext{
62 Cross, "European Transgovernmental Intelligence."

63 Politi, "European Intelligence Necessary?"
} 
Politics and Society 14, no. 3 (2013): 388-402.

European Union Law. Military Staff of the European Union. Accessed August 17, 2010, http://europa.eu/legislation summaries/foreign_and_security_policy/cfsp_and_esdp_implementation/r00006_en.htm.

European Union External Action. “The European Union Satellite Centre.” Accessed May 25, 2014. http://www.eeas. europa.eu/csdp/structures-instruments-agencies/eu-agencies-on-csdp/eu-satellite-centre/index_en.htm.

European Union Military Staff. "Providing Military Capabilities to the EU.” Accessed August 20, 2010. http://www. consilium.europa.eu/uedocs/cmsUpload/EUMS-June-2010.pdf.

Jones, Chris. “Analysis: Secrecy Reigns at the EU's Intelligence Centre.” Statewatch 22, no. 4 (2013). Accessed May 24, 2014. http://www.statewatch.org/analyses/no-223-eu-intcen.pdf.

Lefebvre, Stéphane. "The Difficulties and Dilemmas of International Intelligence Cooperation."International Journal of Intelligence and Counterintelligence 16, no. 4 (2003): 527 -542.

Lemieux, Frederic. "Information Technology and Criminal Intelligence: A Comparative Perspective." In Technocrime: Technology, Crime and Social Control, edited by Stephane Leman-Langlois, 139-68. Willan Publishing: London, 2013.

Müller-Wille, Björn. "The Effect of International Terrorism on EU Intelligence Co-operation.” JCMS 46, no.1 (2008): 49-73.

—_ "EU Intelligence Co-operation. A Critical Analysis." Contemporary Security Policy 23, no. 2 (2002): 61-86.

Nomikos, John. "Does the European Union Need a Common Intelligence Policy?” Accessed August 18, 2010. http:// www.worldsecuritynetwork.com/showArticle3.cfm?article_id=8661.

— . "European Union Intelligence Agency: A Necessary Institution for Common Intelligence Policy?" In Contemporary Issues and Debates in EU Policy: The European Union and International Relations, edited by Vassiliki N. Koutrakou. Manchester University Press: Manchester, 2004.

Politi, Alessandro. "Why is a European Intelligence Necessary?" In Towards a European Intelligence Policy, edited by Alessandro Politi. Institute for Security Studies, 1998.

Schreier, Fred. WMD Proliferation: Reforming the Security Sector to Meet the Threat. Virginia: Potomac Books, 2009.

Walsh, I. James. "Intelligence Sharing in the European Union: Institutions Are Not Enough.” JCMS 44, no. 3 (2006): 625-43. 